\title{
Selected reactive oxygen species and antioxidant enzymes in common bean after Pseudomonas syringae pv. phaseolicola and Botrytis cinerea infection
}

\author{
Agata Nowogórska $\cdot$ Jacek Patykowski
}

Received: 30 April 2014/Revised: 19 September 2014/Accepted: 14 November 2014/Published online: 30 November 2014

(C) The Author(s) 2014. This article is published with open access at Springerlink.com

\begin{abstract}
Phaseolus vulgaris cv. Korona plants were inoculated with the bacteria Pseudomonas syringae pv. phaseolicola (Psp), necrotrophic fungus Botrytis cinerea $(B C)$ or with both pathogens sequentially. The aim of the experiment was to determine how plants cope with multiple infection with pathogens having different attack strategy. Possible suppression of the non-specific infection with the necrotrophic fungus $B c$ by earlier $P s p$ inoculation was examined. Concentration of reactive oxygen species (ROS), such as superoxide anion $\left(\mathrm{O}_{2}^{-}\right)$and $\mathrm{H}_{2} \mathrm{O}_{2}$ and activities of antioxidant enzymes such as superoxide dismutase (SOD), catalase (CAT) and peroxidase (POD) were determined 6, 12, 24 and $48 \mathrm{~h}$ after inoculation. The measurements were done for ROS cytosolic fraction and enzymatic cytosolic or apoplastic fraction. Infection with $P s p$ caused significant increase in ROS levels since the beginning of experiment. Activity of the apoplastic enzymes also increased remarkably at the beginning of experiment in contrast to the cytosolic ones. Cytosolic SOD and guaiacol peroxidase (GPOD) activities achieved the maximum values $48 \mathrm{~h}$ after treatment. Additional forms of the examined enzymes after specific Psp infection were identified; however, they were not present after single $B C$ inoculation. Subsequent $B c$ infection resulted only in changes of $\mathrm{H}_{2} \mathrm{O}_{2}$ and SOD that occurred to be especially important during plant-pathogen interaction. Cultivar Korona of common bean is considered to be resistant to Psp
\end{abstract}

Communicated by R. Baczek-Kwinta.

A. Nowogórska $(\square) \cdot$ J. Patykowski

Department of Plant Physiology and Biochemistry, Faculty of

Biology and Environmental Protection, University of Łódź,

Banacha 12/16, 90-237, Lodz, Poland

e-mail: nowogorska.agata@gmail.com and mobilises its system upon infection with these bacteria. We put forward a hypothesis that the extent of defence reaction was so great that subsequent infection did not trigger significant additional response.

Keywords Reactive oxygen species - Antioxidant enzymes - Pseudomonas syringae pv. phaseolicola . Botrytis cinerea . Common bean

\section{Introduction}

During ontogenesis, a plant is exposed to many environmental factors including biotic and abiotic stresses. Generally it is accepted that the reactions of plants to necrotrophic pathogens are associated with jasmonic acid (JA) and/or ethylene (ET) signal transduction pathways, while biotrophic pathogens induce salicylic acid (SA) pathway (Glazebrook 2005). In addition, the recent studies have demonstrated that abscisic acid (ABA) is a regulator of plant defence against necrotrophs (Laluk et al. 2011). Adie et al. (2007) observed that ABA-impaired mutants simultaneously showed high susceptibility to Pythium irregulare and Alternaria brassicicola and increased resistance to Botrytis cinerea. Moreover, the authors presented that ABA functioning affected JA-dependent genes and their biosynthesis. Interactions between the mentioned hormones can be either synergistic or antagonistic (Koornneef and Pieterse 2008) bringing about either a positive effect, i.e. optimization of defence response to a pathogen, or producing a negative outcome during multiple infection with pathogens with different lifestyles (Beckers and Spoel 2005). Plant response to various environmental factors is also regulated by ROS and other molecules (Bowler and Fluhr 2000). 
Each plant-pathogen interaction may be characterised by specific features. It can be different depending on plant species and pathogen strains. Moreover, the stage of this interaction influences shifts in functioning of hormone signalling pathways (Derksen et al. 2013). Sometimes a plant exhibits resistance to a specific race of pathogen and it is related to gene-for-gene interactions (Flor 1971). Therefore, comprehensive defence against pathogen attack in plants is a result of a complex interaction between hormones, molecules and their signalling pathways, genetic mechanisms as well as their effects.

Common bean occurs in many varieties both resistant and susceptible to certain pathogens. Most of these plants are susceptible to the necrotrophic fungus Botrytis cinerea $(B c)$. This is mainly due to the attack strategy of this pathogen which consists in direct penetration of a cell wall or lesions using appressorium-like structures developed at the tip of conidial germ tubes (Garcia-Arenal and Sagasta 1980; Williamson et al. 2007). Halo blight caused by $P$. syringae pv. phaseolicola $(P s p)$ is another disease affecting common bean. At the early stages of infection, this pathogen penetrates tissues through lesions and stomata and colonises apoplastic space (Glazebrook 2005). However, in later phases, $P s p$ is necrogenic thus considered as a hemibiotroph (Thaler et al. 2004; Alfano and Collmer 1996).

In response to a biotic stress, a plant triggers a number of defence reactions which may be related either to direct immune responses or to a signal transduction pathway. Oxidative burst resulting in increased activity of the enzymes involved in ROS scavenging is a direct reaction after a pathogen infection. More intensive generation of ROS may increase resistance to some biotrophic pathogens (Lamb and Dixon 1997), however, cell death can promote growth of necrotrophic pathogens. Such reactions were confirmed in both cytosol and apoplast. The latter one is considered to be the first line of defence during pathogen attack and is involved in coordination of various defence reactions (Bolwell et al. 2001).

Peroxidases take part in many physiological processes throughout the whole life of a plant. Due to a large number of their isoforms and heterogeneous regulation of their expression (Passardi et al. 2005) they are good indicators of both biotic and abiotic stresses. Isoenzymes of class III peroxidases are mostly soluble apoplastic and cell wallbound forms (Mika et al. 2010). In addition, they can be generated by post-transcriptional and post-translational modifications (Welinder et al. 2002). Peroxidases play a key role in plant-pathogen interactions, as they strengthen a cell wall by the formation of lignin, dityrosine bonds and of extension cross-links (Passardi et al. 2005). This kind of enzymes may use phenolic compounds especially syringaldazine (Goldberg et al. 1983) and ferulic acid
(Oudgenoeg et al. 2002) as substrates for hydrogen peroxide $\left(\mathrm{H}_{2} \mathrm{O}_{2}\right)$ oxidation.

Superoxide dismutase (SOD) is an enzyme also involved in the metabolism of reactive oxygen species (ROS) by dismutation of superoxide anion to molecular oxygen and $\mathrm{H}_{2} \mathrm{O}_{2}$. Moreover, particular isoforms of SOD interact with other enzymes protecting cells from the oxidative damage (Sakamoto et al. 1995). SOD through the production of $\mathrm{H}_{2} \mathrm{O}_{2}$ cooperates with catalase to control the appropriate level of this reactive oxygen form during infection.

Up to now, there is lack of information how plants cope with sequential infection with incompatible and non-specific pathogens. The aim of this study was to determine whether local reactions of $P$. vulgaris to the incompatible pathogen Psp induce a local response, which would prevent or slow down the non-specific infection with the necrotrophic fungus $B c$. Thus, the levels of ROS and enzymes associated with their metabolism, especially those related to strengthening the structure of the cell wall during infection (including the creation of diferulic bonds), were studied. Therefore, especial attention was paid to reactions in the apoplastic spaces of infected bean leaves.

\section{Materials and methods}

\section{Plant material and pathogen treatment}

4-day-old seedlings of $P$. vulgaris cv. Korona were planted in pots with soil and grown in a growth chamber at temperature of $24{ }^{\circ} \mathrm{C}$ with $16 / 8 \mathrm{~h}$ day/night photoperiod at $70 \%$ humidity. Light was supplied by white fluorescent lamps (36 W Philips TLD 36/84) at $350 \mu \mathrm{E} \mathrm{m}^{-2} \mathrm{~s}^{-1}$ intensity. Then, 14-day-old plants were divided into two groups: control and treated one. Those treated were inoculated with a single pathogen: $P s p$ or $B c$ or sequentially with both pathogens: first the bacterial pathogen and after 2 days the necrotrophic fungus $(P s p+B c) .48 \mathrm{~h}$ was considered to be the optimum time inducing relatively permanent effects after plant response to first pathogen infection. The culture of Psp (strain No IOR 551 obtained from the Institute of Plant Protection in Poznań, Poland) was grown for $48 \mathrm{~h}$ on liquid King B medium at $24^{\circ} \mathrm{C}$ with vigorous shaking, subsequently harvested, centrifuged at 10,000 rpm, rinsed twice, resuspended in sterile distilled water and adjusted to $10^{7} \mathrm{cfu} / \mathrm{cm}^{3}$. The leaves were infiltrated with the bacterial suspension or water (control) using a needleless syringe. $B$. cinerea Pers. (obtained from the Institute of Plant Protection in Poznań, Poland) inoculation was performed by spraying plants with conidia suspension $\left(1.5 \times 10^{6}\left(\mathrm{~cm}^{3}\right)^{-1}\right)$ supplemented with $0.3 \mathrm{mM} \mathrm{H}_{2} \mathrm{KPO}_{4}$ and $2.2 \mathrm{mM}$ glucose. 
Areas of the infected leaves were calculated using the leaf scans imposed on a millimeter scale.

\section{Determination of enzyme activities}

Preparation of apoplastic extract

Apoplastic extracts were obtained from $1 \mathrm{~g}$ fresh weight of common bean leaves. Fluids were obtained according to the method of Polle et al. (1994) modified by Patykowski (2008) as amended, to adapt it to the bean leaves. About $4 \mathrm{~cm}^{2}$ fragments of leaves were washed in deionized water for $5 \mathrm{~min}$ and subsequently vacuum-infiltrated with $10 \mathrm{mM} \mathrm{NaCl}$ in $50 \mathrm{mM}$ phosphate buffer $\mathrm{pH} 6.5$ at $-0.9 \mathrm{kPa}$ pressure at $4{ }^{\circ} \mathrm{C}$ for $10 \mathrm{~min}$. Then the pieces were gently surface dried and centrifuged at $900 \mathrm{~g}$ for $15 \mathrm{~min}$ at $4{ }^{\circ} \mathrm{C}$ in a syringe barrel placed in a centrifuge tube. Apoplastic fluid was rapidly collected and immediately used for enzymatic assays. Purity of the apoplastic fraction was confirmed by the activity of glucose-6phosphate dehydrogenase (Creissen et al. 1999). Contamination with cytoplasm constituents was always less than $1.5 \%$.

\section{Preparation of cytosol extract}

$1 \mathrm{~g}$ of the leaf tissue was homogenised in $5 \mathrm{~cm}^{3}$ of $1 \mathrm{M}$ $\mathrm{NaCl}$ in $50 \mathrm{mM}$ phosphate buffer $\mathrm{pH} 7.0$ containing $1 \mathrm{mM}$ EDTA and $1 \%$ PVP (polyvinylpyrrolidone). Subsequently, the homogenate was centrifuged at $15,000 \mathrm{rpm}$ for $15 \mathrm{~min}$ at $4{ }^{\circ} \mathrm{C}$ and the supernatant was used to analyse enzyme activities.

Guaiacol peroxidase (GPOD, EC 1.11.1.7) activity was measured spectrophotometrically by the modified method of Maehly and Chance (1954) in absorbance at $470 \mathrm{~nm}$ $\left(\varepsilon=26.6 \mathrm{mM}^{-1} \mathrm{~cm}^{-1}\right)$. The final reaction mixture contained $25 \mathrm{mM}$ acetate buffer $\mathrm{pH} 5.6,5 \mathrm{mM}$ guaiacol, $15 \mathrm{mM} \mathrm{H}_{2} \mathrm{O}_{2}$ and the enzyme extract.

Peroxidase with syringaldazine (SPOD) capacity was measured at $530 \mathrm{~nm}\left(\varepsilon=27 \mathrm{mM}^{-1} \mathrm{~cm}^{-1}\right)$ according to the method of Imberty et al. (1985). The total reaction mixture of $2 \mathrm{~cm}^{3}$ contained $50 \mathrm{mM}$ potassium phosphate buffer $\mathrm{pH}$ 6.0, 41.6 $\mu \mathrm{M}$ syringaldazine, $0.11 \mathrm{mM} \mathrm{H}_{2} \mathrm{O}_{2}$ and the enzyme extract.

Peroxidase with ferulic acid (FPOD) activity was measured spectrophotometrically in absorbance at $310 \mathrm{~nm}$ $\left(\varepsilon=11.3 \mathrm{mM}^{-1} \mathrm{~cm}^{-1}\right.$ ) by the method of Takahama (1995). The total reaction mixture of $2 \mathrm{~cm}^{3}$ contained $50 \mathrm{mM}$ potassium phosphate buffer $\mathrm{pH} 7.0,0.14 \mathrm{mM}$ ferulic acid, $0.1 \mathrm{mM} \mathrm{H}_{2} \mathrm{O}_{2}$ and the enzyme extract.

Analysis of superoxide dismutase (SOD, EC 1.15.1.1) activity was based on monitoring its ability to inhibit the photochemical reduction of NBT following the method of Beauchamp and Fridovich (1971). The incubation mixture contained $50 \mathrm{mM}$ potassium phosphate buffer $\mathrm{pH} 7.8$, $13 \mathrm{mM}$ methionine, $75 \mu \mathrm{M}$ NBT, $2 \mu \mathrm{M}$ riboflavin, $0.1 \mathrm{mM}$ EDTA and the enzyme extract. The reaction was started by turning on the UV lamp. The absorbance was measured after $10 \mathrm{~min}$ at wavelength of $560 \mathrm{~nm}$. SOD ability to inhibit $50 \%$ of the photochemical reduction of NBT was used as one unit of its activity.

Catalase (CAT, EC 1.11.1.6) activity was determined using the assay of Dhindsa et al. (1981), which is based on $\mathrm{H}_{2} \mathrm{O}_{2}$ degradation $\left(\varepsilon=36.1 \mathrm{mM}^{-1} \mathrm{~cm}^{-1}\right)$. The total reaction mixture of $2 \mathrm{~cm}^{3}$ contained $50 \mathrm{mM}$ potassium phosphate buffer $\mathrm{pH} 7.0,15 \mathrm{mM} \mathrm{H}_{2} \mathrm{O}_{2}$ and the enzyme extract.

\section{Assays of ROS}

The hydrogen peroxide content was determined using the method described by Capaldi and Taylor (1983). $0.5 \mathrm{~g}$ of the leaf tissue was homogenised in $2.5 \mathrm{~cm}^{3}$ of $5 \%$ trichloroacetic acid (TCA) with addition of $50 \mathrm{mg}$ of activated charcoal in chilled mortars. Subsequently, the homogenates were centrifuged for $10 \mathrm{~min}$ at 15,000 rpm. Supernatants were adjusted to $\mathrm{pH} 3.6$ using $4 \mathrm{M} \mathrm{KOH}$ and were treated as extracts. The reaction mixture contained: $0.2 \mathrm{~cm}^{3}$ of extract and $0.1 \mathrm{~cm}^{3}$ of $3.4 \mathrm{mM} 3$-methyl-2benzothiazolinone hydrazone (MBTH) as well as $0.5 \mathrm{~cm}^{3}$ of horseradish peroxidase (90 U per $100 \mathrm{~cm}^{-3}$ ) solution in $0.2 \mathrm{M}$ sodium acetate buffer $(\mathrm{pH} 3.6)$, which started the reaction. After $2 \mathrm{~min}$, addition of $1.4 \mathrm{~cm}^{3}$ of $1 \mathrm{M} \mathrm{HCl}$ inhibited the reaction. The absorbance at $630 \mathrm{~nm}$ was measured after $15 \mathrm{~min}$.

Histochemical visualisation of hydrogen peroxide was performed according to Thordal-Christensen et al. (1997) DAB staining. The leaves were incubated in an acetate buffer pH 3.8 containing $0.1 \%$ DAB overnight and subsequently rinsed and discoloured with $96 \%$ ethanol.

Superoxide anion concentration was measured according to the method of Doke (1983). Bean leaves were cut into discs $9 \mathrm{~mm}$ in diameter. Then, the discs were incubated for $1 \mathrm{~h}$ in the mixture containing: $50 \mathrm{mM}$ phosphate buffer (pH 7.8), $0.05 \%$ NBT, $0.1 \mathrm{mM}$ EDTA and $0.065 \%$ $\mathrm{NaN}_{3}$. The mixture was then heated at $85{ }^{\circ} \mathrm{C}$ for $15 \mathrm{~min}$ and subsequently cooled. The NBT-reducing activity was presented as an increase in absorbance at $580 \mathrm{~nm} \mathrm{~g}^{-1}$ of fresh weight.

For detection of superoxide anion, the leaves were incubated in $50 \mathrm{mM}$ phosphate buffer $(\mathrm{pH}$ 7.8) containing $0.05 \%$ NBT for $2 \mathrm{~h}$ according to the method of RomeroPuertas et al. (2004) modified by Shi et al. (2010). Then, the leaves were immersed in $96 \%$ ethanol to wash out the chlorophyll. 


\section{Native PAGE}

Native protein electrophoresis was performed at $100 \mathrm{~V}$, on $7.5 \%$ polyacrylamide gel, prepared using modified buffer system of Laemmli (1970). SOD isoenzyme activities were visualised according to the procedure of Beauchamp and Fridovich (1971). The reaction mixture contained: $50 \mathrm{mM}$ phosphate buffer $\mathrm{pH} 7.8,0.245 \mathrm{mM}$ blue nitrotetrazolium (NBT), $1 \mathrm{mM}$ EDTA, $2.8 \mathrm{mM}$ TEMED and $22 \mu \mathrm{M}$ riboflavine.

The gels were incubated for 15-20 min under UV light till light bands appeared. To identify different isoforms of $\mathrm{SOD}, 5 \mathrm{mM} \mathrm{KCN}$ (Cu/Zn-SOD inhibitor) or $5 \mathrm{mM} \mathrm{H}_{2} \mathrm{O}_{2}$ $(\mathrm{Cu} / \mathrm{Zn}-\mathrm{SOD}$ and $\mathrm{Fe}-\mathrm{SOD}$ inhibitor) were used before staining. To visualise POD isoforms, the gels were incubated in $50 \mathrm{mM}$ acetate buffer ( $\mathrm{pH}$ 5.6) with addition of $30 \mathrm{mM} \mathrm{H}_{2} \mathrm{O}_{2}$ and $0.1 \%$ 4-chloro-1-naphthol (dissolved in a minimal volume of $96 \%$ ethanol) for $15 \mathrm{~min}$ and subsequently washed with distilled water. To detect isoenzymes of catalase, the gels were incubated in $0.005 \%$ $\mathrm{H}_{2} \mathrm{O}_{2}$ for $10 \mathrm{~min}$, rinsed twice with distilled water and stained with the reaction mixture containing $2 \%$ ferricyanide $\left[\mathrm{K}_{3} \mathrm{Fe}(\mathrm{CN})_{6}\right]$ and $2 \%$ ferric chloride until light bands appeared.

\section{Preparation of protein extracts}

Bean leaves of each variant were homogenised in 1:5 ratio $(\mathrm{w} / \mathrm{v})$ in $50 \mathrm{mM}$ TRIS-HCl buffer $(\mathrm{pH} 8.0)$ containing $3 \mathrm{mM}$ EDTA, $1 \mathrm{mM}$ DTT, $1 \mathrm{mM} \mathrm{MgCl}_{2}$ and $2 \%$ PVP. Then the homogenates were centrifuged at 20,000 rpm for $20 \mathrm{~min}$. For each lane, 10-15 $\mu$ l of supernatants enriched with sucrose and $0.025 \%$ bromophenol blue were applied.

\section{Analysis of protein content}

Protein content was measured by the method of Bradford (1976) using bovine serum albumin as a standard.

\section{Statistical analysis}

Sample variability for three or four replicates was given as standard deviation of mean. The statistical analyses were performed using Mann-Whitney rank sum test. Statistically significant differences were accepted at $P \leq 0.05$.

\section{Results}

Infected leaf area and ROS generation

Plant-pathogen interaction is often associated with an increase in the concentrations of reactive oxygen species and enzymes involved in their scavenging/generation. Inoculation of the plant with pathogens triggered a range of morphological symptoms. Chlorotic and necrotic lesions after $P s p$ infiltration and necrosis caused by $B c$ development were observed. However, the infected area after subsequent $B c$ infection was not much larger compared to the single Psp variant (Table 1). These changes mainly resulted from the accumulation of reactive oxygen species in plant tissues, especially hydrogen peroxide and superoxide anion, which was confirmed by DAB and NBT staining (Fig. 1). Increase in ROS generation was observed especially in the areas nearest to those infected with $B c$ and Psp. Superoxide anion is produced as a result of one-electron reduction of molecular oxygen and can be quite toxic to cell compartments. After Psp treatment, the level of $\mathrm{O}_{2}^{\bullet-}$ increased starting from 12th hour to the end of the experiment (Fig. 2). Significantly higher superoxide anion concentration after $B c$ inoculation was only noticeable $6 \mathrm{~h}$ after plant treatment. Infection of leaves with both pathogens resulted in significantly increased $\mathrm{O}_{2}^{\bullet-}$ level as early as $6 \mathrm{~h}$ after $B c$ inoculation and reached the maximum value ( $212 \%$ of the control) after $12 \mathrm{~h}$. Significantly higher concentrations of hydrogen peroxide were observed as early as $6 \mathrm{~h}$ after Psp inoculation, with the largest value $48 \mathrm{~h}$ after treatment $(281 \%$ of the control) which persisted until 96th $\mathrm{h}$ of the experiment (Fig. 3c). $B c$ treatment caused less intensive production of $\mathrm{H}_{2} \mathrm{O}_{2}$ compared to the $P s p$ variant. The results of the combined $P s p+B c$ treatment were similar to those for $P s p$ alone.

\section{Assessment of enzyme activities}

Superoxide dismutase is an enzyme responsible for $\mathrm{O}_{2}^{\bullet-}$ dismutation to $\mathrm{H}_{2} \mathrm{O}_{2}$. This reactive oxygen form was measured in the whole leaf tissue, although it can be generated both by superoxide dismutase derived from cytosolic and apoplastic fraction. After bacterial treatment, the only significant changes in the apoplastic SOD activity were observed 6, 12 and $24 \mathrm{~h}$ after inoculation and in the cytosolic pool of SOD after 60, 72 and 96 h (Fig. 3a, b).

Table 1 Area of infected leaves of $P$. vulgaris $48 \mathrm{~h}$ after inoculation with $B c, P s p$ or $P s p+B c$ analysed $96 \mathrm{~h}$ after $P s p$ inoculation and $48 \mathrm{~h}$ after $B c$ treatment

\begin{tabular}{lllll}
\hline Variant & Control & $P s p$ & $B c$ & $P s p+B c$ \\
\hline $\begin{array}{l}\% \text { of } \\
\text { infected } \\
\text { leaf area }\end{array}$ & 0 & $7.24 \pm 0.61 *$ & $6.73 \pm 0.96^{*}$ & $8.17 \pm 0.85^{*}$ \\
\hline
\end{tabular}

Values are means with SD

* Significant differences from the control at $P<0.05$. No differences between particular treatments were found 


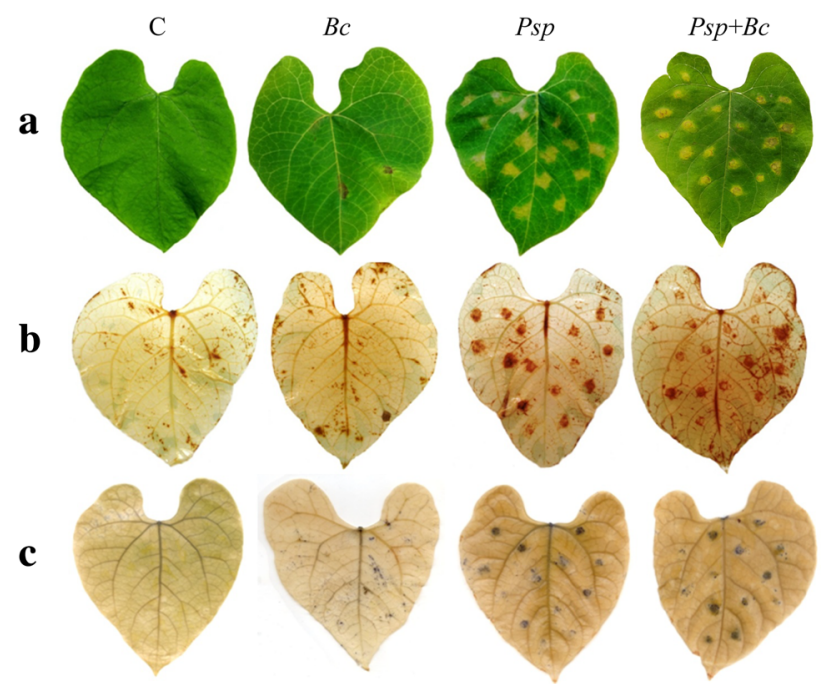

Fig. 1 Visualisation of $\mathrm{H}_{2} \mathrm{O}_{2}$ (b) and $\mathrm{O}_{2}^{--}$(c) in the leaves of $P$. vulgaris $48 \mathrm{~h}$ after inoculation with $B c$ and $P s p ; P s p+B c$ analysed $96 \mathrm{~h}$ after $P s p$ inoculation and $48 \mathrm{~h}$ after $B c$ treatment; a leaves without staining

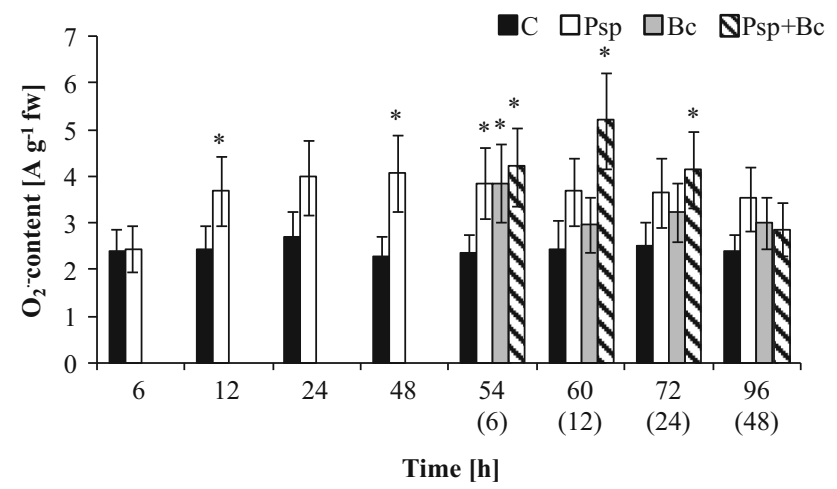

Fig. 2 Superoxide anion concentration in the primary leaves of $P$. vulgaris inoculated with $P$. syringae pv. phaseolicola $(P s p)$ or $B$. cinerea $(B c)$ or with both pathogens sequentially $(P s p+B c)$ compared to the control (C). Hours in parentheses refer to the time after $B c$ inoculation. Values are means with SD; asterisk indicates significant differences from the control at $P<0.05$

Treating plants with the fungal pathogen caused the maximum increase (twofold) in cytosolic pool of SOD amount $48 \mathrm{~h}$ after inoculation. Sequential $P s p+B c$ infection resulted in the significant SOD enhancement after $48 \mathrm{~h}$. Catalase is an enzyme responsible for the removal of high concentrations of $\mathrm{H}_{2} \mathrm{O}_{2}$. Psp inoculation resulted in a slight decrease (6-24 h after inoculation) in the cytosolic activity of this enzyme, compared to the control (Fig. 4a). Statistically significant change in the catalase amount was observed only $6 \mathrm{~h}$ after $B c$ treatment. In other variants, no significant changes were observed. Peroxidase is another enzyme considered to be involved in $\mathrm{H}_{2} \mathrm{O}_{2}$ scavenging. It is supposed that phenolic compounds, such as syringaldazine
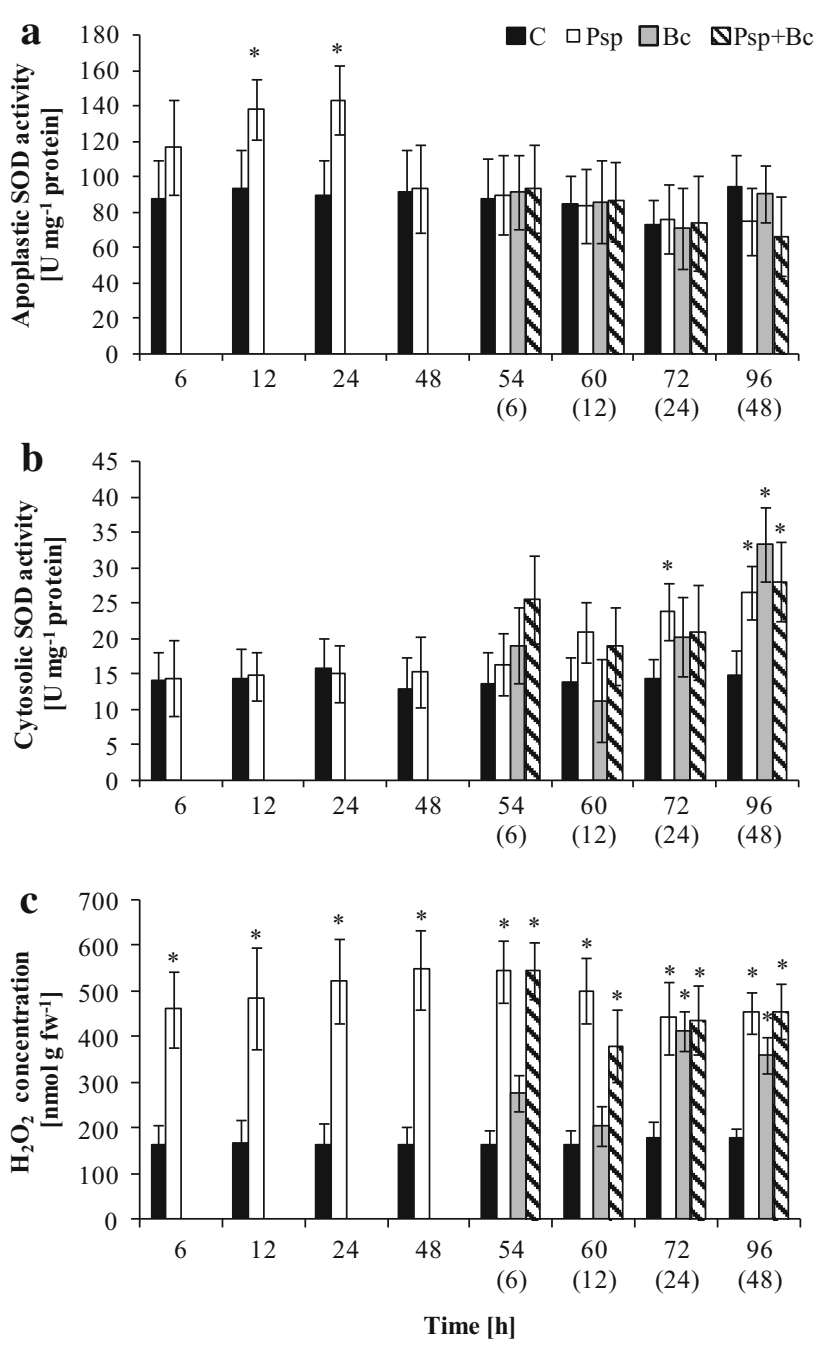

Fig. 3 Time course of changes of superoxide dismutase activity in the apoplastic (a) and cytosolic (b) fraction and hydrogen peroxide concentration (c) in common bean leaves inoculated with $P$. syringae pv. phaseolicola $(P s p)$ or B. cinerea $(B c)$ or with both pathogens sequentially $(P s p+B c)$ compared to the control (C). Hours in parentheses refer to the time after $B c$ inoculation. Values are means with SD; asterisk indicates significant differences from the control at $P<0.05$

and ferulic acid, take part in cell wall strengthening, and increased activity of peroxidases assayed with these substrates is of particular importance during infection. Increased levels of GPOD in the apoplastic fraction started $6 \mathrm{~h}$ after $P s p$ treatment and remained quite high to the end of the experiment, which indicate involvement of the total pool of peroxidase during infection (Fig. 5b). Fungal inoculation caused systematic increase in guaiacol peroxidase with the maximum value after $48 \mathrm{~h}$. Its activities in the $P s p+B c$ variant were very similar to $P s p$. The cytosolic fraction showed a slight increase in GPOD activities from 54th up to 96th h after $P s p$ treatment, while $B c$ inoculation caused significant changes starting from 6 th $\mathrm{h}$ until 48 th $\mathrm{h}$ 


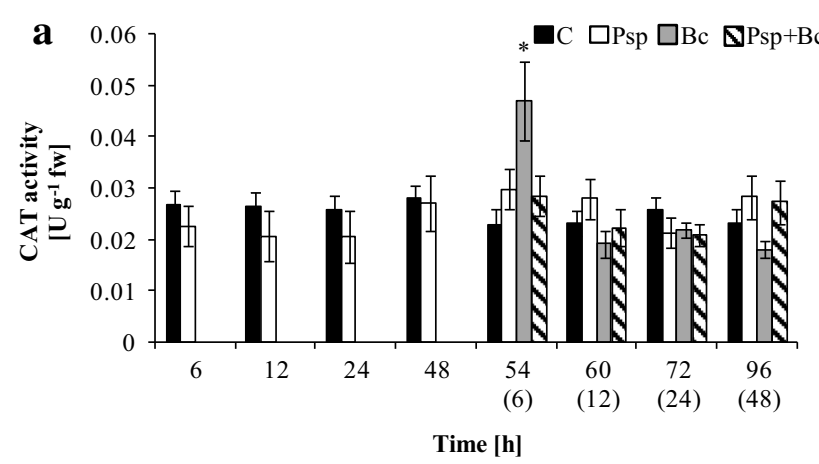

b
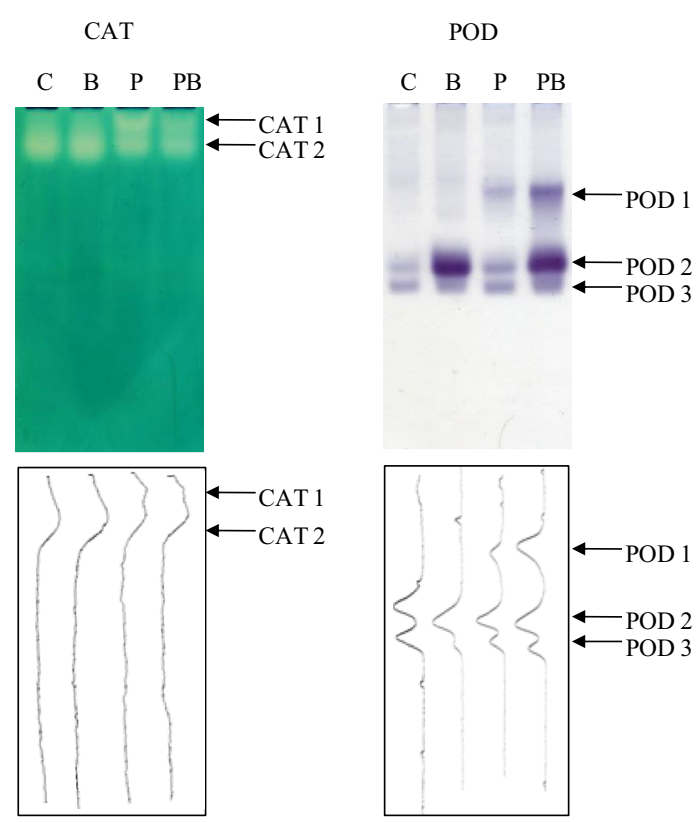

Fig. 4 a Time course of changes of catalase activity in the cytosolic fraction of common bean leaves inoculated with $P$. syringae pv. phaseolicola $(P s p)$ or $B$. cinerea $(B c)$ or with both pathogens sequentially $(P s p+B c)$ compared to the control (C). Hours in parentheses refer to the time after $B c$ inoculation. Values are means with SD; asterisk indicates significant differences from the control at $P<0.05$. b Identification of CAT and POD isoforms from Phaseolus vulgaris leaves inoculated with $P s p$ and $B c$ on native PAGE and the corresponding densitograms. Electrophoretic patterns for control (C), $P s p$ (P) and $B c$ (B) single variants were obtained $48 \mathrm{~h}$ after inoculation, while $P s p+B c$ (PB) variant was analysed $96 \mathrm{~h}$ after $P s p$ inoculation and $48 \mathrm{~h}$ after $B c$ treatment

(Fig. 5a). The most marked enhancement of this enzyme was noticed for $P s p+B c 48 \mathrm{~h}$ after fungal inoculation. High activities of FPOD and SPOD in apoplast were observed $6 \mathrm{~h}$ after $P s p$ inoculation, and over time decreased to the values comparable to the control in 96th $\mathrm{h}$ of experiment (Fig. 6a, b). On the contrary, $B c$ treatment caused gradual increase in these enzymes with the maximum value after $48 \mathrm{~h}$, which was better noticeable in FPOD activity. Peroxidase activity measured with ferulic acid after sequential infection did not differ significantly from the $P s p$ variant.
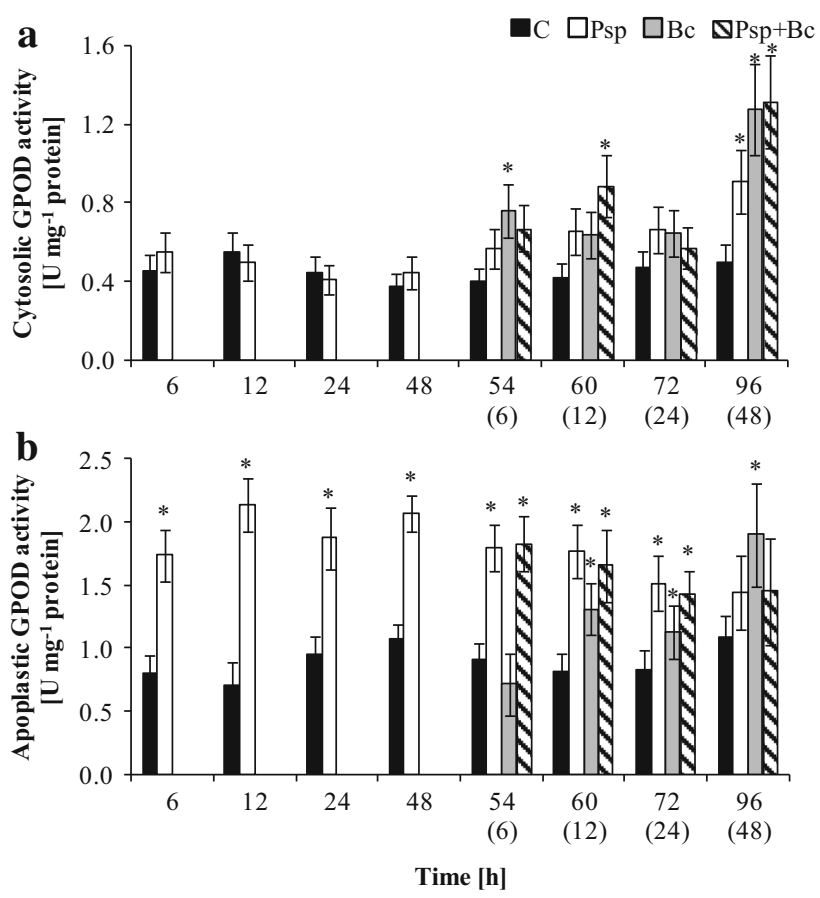

Fig. 5 Time course of changes of guaiacol peroxidase activity in the cytosolic (a) and apoplastic (b) fraction of common bean leaves inoculated with $P$. syringae pv. phaseolicola $(P s p)$ or $B$. cinerea $(B c)$ or with both pathogens sequentially $(P s p+B c)$ compared to the control (C). Hours in parentheses refer to the time after $B c$ inoculation. Values are means with SD; asterisk indicates significant differences from the control at $P<0.05$

\section{Native PAGE}

Analysis of SOD isoenzymes on native PAGE showed the presence of $2 \mathrm{Mn}$-SODs isoforms, $2 \mathrm{Cu} / \mathrm{Zn}$-SODs isoforms and $2 \mathrm{Fe}$-SODs isoenzymes, of whose one was specific for $P s p$ inoculation and persisted also after $P s p+B c$ infection (Fig. 7). CAT patterns on native PAGE showed 1 isoform characteristic of the control plants and $B c$ infection and 1 additional form of this enzyme in both $P s p$ and $P s p+B c$ variants (Fig. 4b).

Native PAGE revealed the presence of 3 POD isoforms, of whose an extra POD form appeared after Psp inoculation and persisted also in the case of sequential infection with $B c$ (Fig. 4b).

\section{Discussion}

Botrytis cinerea is a necrotrophic fungus secreting a number of specific toxins leading to cell death. It was shown that fluorescently labelled $B c \mathrm{NEP} 1$ and $B c \mathrm{NEP} 2$ toxins derived from $B$. cinerea were associated with plasma membranes and the nuclear envelope, as well as they were present in the nuclei of responding plant cells. These toxins 

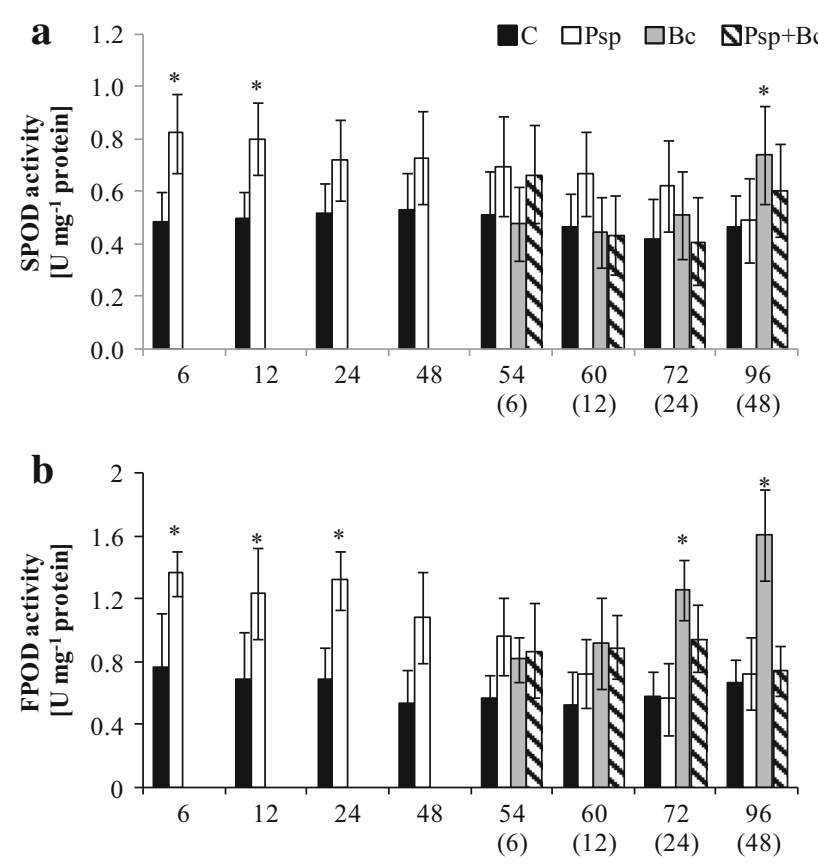

Time [h]

Fig. 6 Time course of changes of peroxidase with syringaldazine (a) and ferulic acid (b) activity in the apoplastic fraction of common bean leaves inoculated with $P$. syringae pv. phaseolicola $(P s p)$ or $B$. cinerea $(B c)$ or with both pathogens sequentially $(P s p+B c)$ compared to the control $(C)$. Hours in parentheses refer to the time after $B c$ inoculation. Values are means with SD; asterisk indicates significant differences from the control at $P<0.05$

may induce a strong hydrogen peroxide accumulation that was observed in chloroplasts. The cell death may occur as apoptosis, necrosis or intermediate forms (Schouten et al. 2007). A cell wall is a complicated structure that serves both as a constitutive defence and as an active and dynamic barrier in response to signals from pathogens (Huckelhoven 2007). Moreover, hydrogen peroxide as well as peroxidases can participate in strengthening a cell wall (Mayer et al. 2001; Burr and Fry 2009). The changes of peroxidase activity in cell wall surroundings during creation of crosslinking differulate in the wall were probably governed by fluctuations in $\mathrm{H}_{2} \mathrm{O}_{2}$ and/or presence of its inhibitors (Encina and Fry 2005). The same authors found that crosslinking of [14C]feruloyl-arabinoxylans also occurred in vitro, in the presence of endogenous peroxidases plus exogenous $\mathrm{H}_{2} \mathrm{O}_{2}$. Van Baarlen et al. (2007) confirmed that cell-wall-located ROS production during Botrytis $s p$. colonisation was often accompanied by production of phenolic compounds. Psp colonising mainly apoplastic spaces affects cell walls and specific enzymes bound with them which results in increase in their activity.

Our studies showed that high activity of peroxidase within a cell wall as early as $6 \mathrm{~h}$ after Psp infection was correlated with great concentration of hydrogen peroxide,

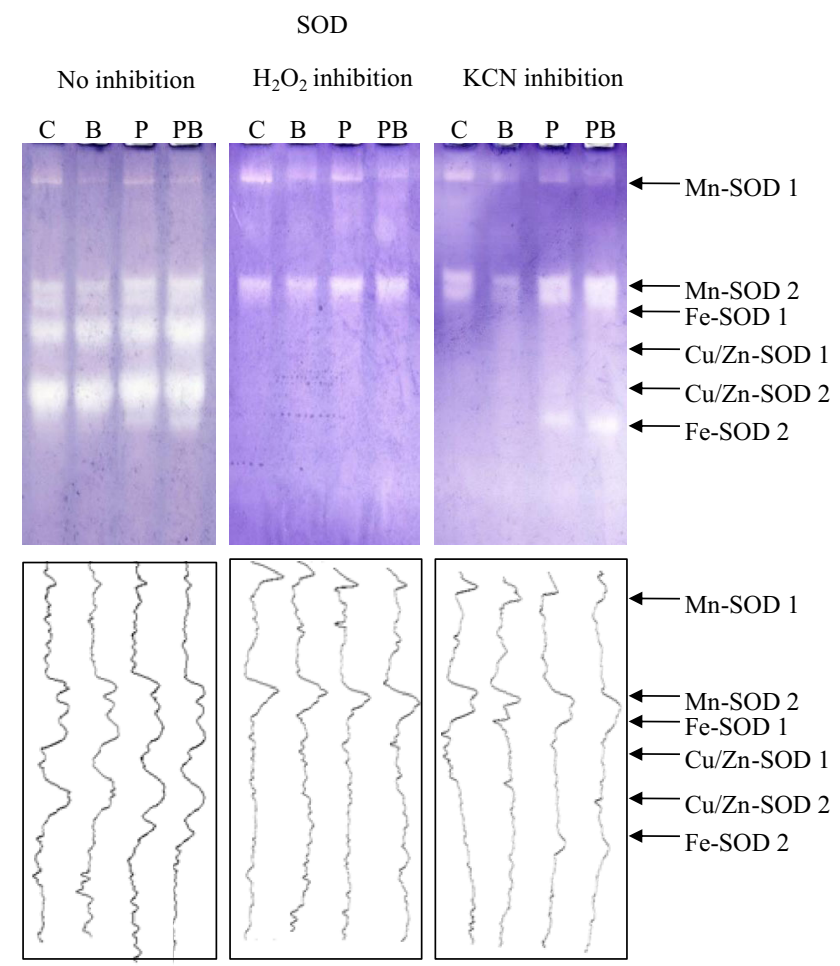

Fig. 7 Identification of different SOD isoforms from $P$. vulgaris leaves inoculated with $P s p$ and $B c$ on native PAGE with KCN and $\mathrm{H}_{2} \mathrm{O}_{2}$ inhibition and the corresponding densitograms. Electrophoretic patterns for control (C), Psp (P) and $B c$ (B) single variants were obtained $48 \mathrm{~h}$ after inoculation, while $P s p+B c(\mathrm{~PB})$ variant was analysed $96 \mathrm{~h}$ after $P s p$ inoculation and $48 \mathrm{~h}$ after $B c$ treatment

which is the major form of ROS taking part in oxidative burst (Wojtaszek 1997). It can be assumed that overproduction of $\mathrm{H}_{2} \mathrm{O}_{2}$ is used to form diferulic bridges responsible for cell wall strengthening and participates in defence reactions against attack of incompatible pathogens. No significant additional enzymatic activity or ROS generation after sequential infection may suggest that the plant response to the bacterial pathogen was strong enough, mainly due to the fact that it is considered to be resistant to $P s p$. However, sequential infection by $B c$ induced slight increase in SOD activity in the cytosolic fraction $6 \mathrm{~h}$ after inoculation which was correlated with increased ROS generation. This may suggest that some mobilisation of resistance enzymes after second infection is possible. It can be assumed that the additional form of Fe-SOD appearing after $P s p$ infection and persisting after sequential $P s p+B c$ infection might inhibit $B c$ development through the production of hydrogen peroxide, providing that CAT activity was low. Thus, the suppression of CAT activity contributed to higher generation of toxic $\mathrm{H}_{2} \mathrm{O}_{2}$ whose greater concentration may inhibit not only incompatible pathogen infection. On the other hand, high CAT activity $6 \mathrm{~h}$ after $B c$ infection resulted in reduced amount of hydrogen peroxide 
which could increase $B c$ expansion. Such results confirm a combined action of SOD and CAT in response to contact with microorganisms observed by Baptista et al. (2007) and Schwacke and Hager (1992). CAT was also found to be down-regulated at the transcription level during HR (Dorey et al. 1998). It is interesting that the induction of the additional Fe-SOD form, sensitive to high concentrations of $\mathrm{H}_{2} \mathrm{O}_{2}$, coincided with increased plant resistance (even after sequential infection). This fact may suggest that the produced $\mathrm{H}_{2} \mathrm{O}_{2}$ participated in the plant-pathogen interaction, therefore, its level was not high enough to inhibit Fe-SOD.

The increased GPOD activity after bacterial infection may suggest more intensive use of overgenerated $\mathrm{H}_{2} \mathrm{O}_{2}$ in the oxidation of phenolic compounds which can be the inhibitors of both bacteria and fungi growth. Their ability to inhibit the activity of enzymes, i.e. those derived from pathogens, and thereby to suppress growth of pathogens has been repeatedly confirmed (Mellersh et al. 2002; Lebeda and Sedlarova 2003; Sedlářová et al. 2004). In our work, the GPOD activity measured in the apoplastic fraction increased after both Psp and sequential infection with both pathogens. It proves that the most important processes during plant-pathogen interaction occur around a cell wall, which is the first barrier of cell defence. $P s p+B c$ infection resulted in increased GPOD activity, comparable to that after single $P s p$ infection. Such results showed that after sequential infection with $B c$, there was no additional increase in the activity above that obtained after Psp application.

The results obtained for the SPOD and FPOD activities seem to be of special interest. Peroxidase activity measured with syringaldazine as a substrate is assumed to be involved in cell wall lignification. Our results showed its increased activity after $P s p$ treatment but subsequent $B c$ inoculation $(P s p+B c)$ did not change SPOD level in comparison to the $P s p$ variant. Only $B c$ infection caused an increased SPOD activity at the end of the experiment.

Since pathogenic bacteria and fungi exhibit various toxicity towards plants they may be expected to induce different kinds of response, e.g. necrotrophs produce extracellular enzymes damaging plant cell walls and inducing apoptotic-like cell death (Shlezinger et al. 2011). Therefore, it was important to determine FPOD activity in the apoplastic fraction. It was found out that its activity associated with the formation of additional diferulic bonds by apoplastic peroxidase increased after Psp infection since the beginning of the experiment and even stronger than that of SPOD after $B c$ inoculation. Sequential $P s p+B c$ infection did not cause increase in the FPOD activity above the levels obtained after single $P s p$ or $B c$ inoculation.

Plant response to bacterial and fungal infection can differ remarkably and depends on a broad spectrum of reactions such as interactions between different plant hormones regulating defence gene expression and pathogen resistance (Thomma et al. 1998). Enhanced generation of reactive oxygen species is characteristic of reactions to both biotrophic and necrotrophic pathogens. These molecules not only participate in intercellular signalling, but locally at excessive concentration they can be also toxic to pathogens (Mehdy 1994, Mayer et al. 2001). Stress related to infection induces alterations in plant gene expression patterns mainly involved in redeployment of cell functions from metabolic processes to defence reactions (Takahashi et al. 2004). Finiti et al. (2013) demonstrated that transgenic tomato plants, having greater susceptibility to $P$. syringae, exhibited increased expression of the marker gene of jasmonic acid pathway after infection. They showed that endo-1,4-b-glucanases were differentially expressed upon many different plant-pathogen challenges, hormone treatments and many abiotic stresses. They demonstrated that the reduced activity of this enzyme could alter the impact of plant pathogens and could contribute to the respective signalling and resulted in a variety of plant responses to biotic and abiotic stresses.

Recent studies on plant resistance mechanisms have confirmed the presence of genes responsible for the response to both biotic and abiotic factors (AbuQamar et al. 2013). Mengiste et al. (2003) in the research on A. thaliana demonstrated the presence of $B O S 1$ gene activated by $B$. cinerea infection. BOS1 gene expression resulted in inhibition of infection not only by $B$. cinerea, but also by another necrotroph $A$. brassicicola, suggesting a similar defensive strategy against these pathogens. bos 1 mutants with greater susceptibility to $B$. cinerea exhibited also increased sensitivity to oxidative stress caused by abiotic factors. Furthermore, BOS1 expression was blocked in plants with coi1 mutation which causes insensitivity to jasmonic acid and higher sensitivity to Botrytis. It has been suggested that the protein encoded by BOS1 (transcript R2R3MYB protein) together with JA is responsible for the activation of a signal cascade of reactive oxygen intermediates (ROI).

Studies on tomato plants (Solanum lycopersicum) proved the presence of SIAIM1 gene whose expression is regulated by abscisic acid (ABA) (AbuQamar et al. 2009). Plants with reduced expression of this gene were characterised by increased susceptibility to both $B$. cinerea infection and salt stress. The authors suggested a correlation between ABA, the ability to maintain $\mathrm{Na}^{+}$homeostasis, oxidative stress and response to pathogens.

AbuQamar et al. (2013) also demonstrated that similarly to the results obtained for $A$. thaliana, EXLA2 gene encoding expansin, involved in cell wall modification, played an important role during $B$. cinerea infection. The authors showed that in exla 2 mutants with decreased susceptibility to $B$. cinerea sensitivity to infection with $P$. syringae pv. tomato was not changed. Moreover, EXLA2 
gene activation was induced by abiotic factors such as salinity, cold or exogenous ABA application. It has been suggested that lack or deregulation of EXLA2 gene expression may be of importance for increasing resistance to $B$. cinerea. As in the previous study, they demonstrated that exla2 mutants were hypersensitive to cold and salinity for which the response is regulated by a metabolic pathway of $\mathrm{ABA}$.

It seems that in the case of our study on bean, the presence of a specific gene activated upon the infection with Psp, whose expression might down-regulate the early development of the second infection with $B c$, cannot be excluded at least at the beginning of this process. The area of lesions $48 \mathrm{~h}$ after subsequent $B c$ inoculation was smaller than in the case of a single primary infection with this necrotroph. Certainly, ROS generation initiated by $P s p$ inoculation may be involved in further resistance to subsequent pathogen attack.

\section{Conclusion}

Our results suggest, that $P$. vulgaris $\mathrm{cv}$. Korona, resistant to $P s p$, after inoculation with this pathogen mobilised the immune system to such an extent that after contact with the necrotrophic pathogen only $\mathrm{H}_{2} \mathrm{O}_{2}$ and SOD levels, crucial for further resistance, changed. This may indicate that the induction of enzymatic response after $P s p$ allowed to delay growth of the necrotrophic pathogen. Increased FPOD and SPOD activities were observed both after $P s p$ and $B c$ infection which may indicate their important role in strengthening plant cell walls during different kinds of infections. However, increased generation of $\mathrm{H}_{2} \mathrm{O}_{2}$ and higher SOD activity as well as additional Fe-SOD form after $P s p$ inoculation with slight increase in these parameters after subsequent $B c$ infection may confirm the specificity of the response to $P s p$ which confers increased resistance to $B c$ at the early stages of infection.

Author contribution Agata Nowogórska was responsible for carrying out the experiment and working out the results and Jacek Patykowski was responsible for the idea and coordination of the experiment.

Open Access This article is distributed under the terms of the Creative Commons Attribution License which permits any use, distribution, and reproduction in any medium, provided the original author(s) and the source are credited.

\section{References}

AbuQamar S, Luo H, Laluk K, Mickelbart MV, Mengiste T (2009) Crosstalk between biotic and abiotic stress responses in tomato is mediated by the AIM1 transcription factor. Plant J 58:347-360
AbuQamar S, Ajeb S, Sham A, Enan MR, Iratni R (2013) A mutation in the expansin-like A2 gene enhances resistance to necrotrophic fungi and hypersensitivity to abiotic stress in Arabidopsis thaliana. Mol Plant Pathol 14(8):813-827

Adie BA, Pérez-Pérez J, Mm Pérez-Pérez, Godoy M, SánchezSerrano JJ, Schmelz EA, Solano R (2007) ABA is essential signal for plant resistance to pathogens affecting JA biosynthesis and the activation of defences in Arabidopsis. Plant Cell 19:1665-1681

Alfano JR, Collmer A (1996) Bacterial pathogens in plants: life up against the wall. Plant Cell 8:1683-1698

Baptista P, Martins A, Pais MS, Tavares RM, Lino-Neto T (2007) Involvement of reactive oxygen species during early stages of ectomycorrhiza establishment between Castanea sativa and Pisolithus tinctorius. Mycorrhiza 17:185-193

Beauchamp C, Fridovich I (1971) Superoxide dismutase: improved assays and an assay applicable to acrylamide gels. Anal Biochem 44:276-287

Beckers GJM, Spoel SH (2005) Fine-tuning plant defence signalling: salicylate versus jasmonate. Plant Biol 8:1-10

Bolwell PP, Page A, Piślewska M, Wojtaszek P (2001) Pathogenic infection and the oxidative defences in plant apoplast. Protoplasma 217:20-32

Bowler C, Flur R (2000) The role of calcium and activated oxygens as signals for controlling cross-tolerance. Trends Plant Sci 5:241-246

Bradford MM (1976) A rapid and sensitive method for the quantitation of microgram quantities of protein utilizing the principle of protein-dye binding. Anal Biochem 72:248-254

Burr SJ, Fry SF (2009) Extracellular cross-linking of maize arabinoxylans by oxidation of feruloyl esters to form oligoferuloyl esters and ether-like bonds. Plant J 58:554-567

Capaldi DJ, Taylor KE (1983) A new peroxidase colour reaction: oxidative coupling of 3-methyl-2-benzothiazolinone hydrazone (MBTH) with its formaldehyde azine application to glucose and choline oxidases. Anal Biochem 129:329-336

Creissen G, Firmin J, Freyer M, Kular B, Leyland N, Reynold H, Pastori G, Wellburn F, Baker N, Wellburn A, Mullineaux P (1999) Elevated glutathione biosynthetic capacity in the chloroplasts of transgenic tobacco paradoxically caused increased oxidative stress. Plant Cell 11:1277-1291

Derksen H, Rampitsch C, Daayf F (2013) Signaling cross-talk in plant disease resistance. Plant Sci 207:79-87

Dhindsa RS, Plumb-Dhindsa P, Thorpe TA (1981) Leaf senescence correlated with increased levels of membrane permeability and lipid peroxidation, and decreased levels of superoxide dismutase and catalase. J Exp Bot 32:93-101

Doke N (1983) Involvement of superoxide anion generation in the hypersensitive response of potato tuber tissues to infection with an incompatible race of Phytophthora infestans and to the hyphal wall components. Physiol Plant Pathol 23:345-357

Dorey S, Bailleul F, Saindrenan P, Fritig B, Kauffmann S (1998) Tobacco class I and II catalases are differentially expressed during elicitor induced hypersensitive cell death and localized acquired resistance. Mol Plant Microb Int 11:1102-1109

Encina A, Fry SC (2005) Oxidative coupling of a feruloylarabinoxylan trisaccharide (FAXX) in the walls of living maize cells requires endogenous hydrogen peroxide and is controlled by a low-Mr apoplastic inhibitor. Planta 223:77-89

Finiti I, Leyva MO, López-Cruz J, Calderan Rodrigues B, Vicedo B, Angulo C, Bennett AB, Grant M, Garcia-Agustın P, GonzálezBosch C (2013) Functional analysis of endo-1,4-b-glucanases in response to Botrytis cinerea and Pseudomonas syringae reveals their involvement in plant-pathogen interactions. Plant Biol $15: 819-831$ 
Flor HH (1971) Current status of the gene-for-gene concept. Annu Rev Phytopathol 9:275-296

Garcia-Arenal F, Sagasta EM (1980) Scanning electron microscopy of Botrytis cinerea penetration of bean (Phaseolus vulgaris) hypocotyls. Phytopathol Z 99:37-42

Glazebrook J (2005) Contrasting mechanisms of defense against biotrophic and necrotrophic pathogens. Annu Rev Phytopathol 43:205-227

Goldberg R, Catesson AM, Czaninski Y (1983) Some properties of syringaldazine oxidase, a peroxidase specifically involved In the lignification processes. Z Pflanzenphysiol 110:267-279

Huckelhoven R (2007) Cell wall-associated mechanisms of disease resistance and susceptibility. Annual Rev Phytopathol 45:101-127

Imberty A, Goldberg R, Catesson AM (1985) Isolation and characterization of Populus isoperoxidases involved in the last step of lignification. Planta 164:221-226

Koornneef A, Pieterse CMJ (2008) Cross talk in defense signalling. Plant Physiol 146:839-844

Laemmli UK (1970) Cleavage of structural proteins during the assembly of the head of bacteriophage T4. Nature 227:680-685

Laluk K, AbuQamar S, Mengiste T (2011) The Arabidopsis mitochondrial localized pentatricopeptide repeat protein PGN functions in defense against necrotrophic fungi and abiotic stress tolerance. Plant Physiol 156:2053-2068

Lamb C, Dixon RA (1997) The oxidative burst in plant disease resistance. Annu Rev Plant Physiol Plant Mol Biol 48:251-275

Lebeda A, Sedlarova M (2003) Cellular mechanisms involved in the expression of specificity in Lactuca spp-Bremia lactucae interactions. In: Hintum ThJL. Van-Lebeda A, Pink DAC, Schut JW (eds) Eucarpia leafy vegetables conference 2003. CGN, Wageningen, The Netherlands, pp 55-60

Maehly AC, Chance B (1954) The assay of catalases and peroxidases. In: Glick D (ed) Methods of biochemical analysis. Willey, New York, pp 357-425

Mayer AM, Staples RC, Gilad NL (2001) Mechanisms of survival of necrotrophic fungal plant pathogens in hosts expressing the hypersensitive response. Phytochemistry 58(1):33-41

Mehdy MC (1994) Active oxygen species in plant defense against pathogens. Plant Physiol 105(2):467-472

Mellersh DG, Foulds IV, Higgins VJ, Heath MC (2002) $\mathrm{H}_{2} \mathrm{O}_{2}$ plays different roles in determining penetration failure in three diverse plant-fungal interactions. Plant J 29:257-268

Mengiste T, Chen X, Salmeron J, Dietrich R (2003) The BOTRYTIS SUSCEPTIBLE1 gene encodes an R2R3MYB transcription factor protein that is required for biotic and abiotic stress responses in Arabidopsis. Plant Cell 15:2551-2565

Mika A, Boenisch MJ, Hopff D, Lüthje S (2010) Membrane-bound guaiacol peroxidases from maize (Zea mays L.) roots are regulated by methyl jasmonate, salicylic acid, and pathogen elicitors. J Exp Bot 61(3):831-841

Oudgenoeg G, Dirksen E, Ingemann S, Hilhorst R, Gruppen H, Boeriu CG, Piersma SR, van Berkel WJH, Laane C, Voragen AGJ (2002) Horseradish peroxidase-catalyzed oligomerization of ferulic acid on a template of a tyrosine-containing tripeptide. J Biol Chem 24(277):21332-21340

Passardi F, Cosio C, Penel C, Dunand C (2005) Peroxidases have more functions than a Swiss army knife. Plant Cell Rep $24: 255-265$

Patykowski J (2008) Rola apoplastu w interakcji roślina-patogen po infekcji pomidora przez Botrytis cinerea. Wydawnictwo Uniwersytetu Łódzkiego, Łódź

Polle A, Otter T, Seifert F (1994) Apoplastic peroxidases and lignification in needles of Norway Spruce (Picea abies). Plant Physiol 106:53-60
Romero-Puertas MC, Rodríguez-Serrano M, Corpas FJ, Gómez M, Del Río LA, Sandalio LM (2004) Cadmium-induced subcellular accumulation of $\mathrm{O}_{2}^{--}$and $\mathrm{H}_{2} \mathrm{O}_{2}$ in pea leaves. Plant Cell Environ 27:1122-1134

Sakamoto A, Okumura T, Kaminaka H, Sumi K, Tanaka K (1995) Structure and differential response to abscisic acid of two promoters for the cytosolic copper/zinc-superoxide dismutase genes, SodCc1 and $\operatorname{SodCc} 2$, in rice protoplasts. FEBS Lett 358:62-66

Schouten A, van Baarlen P, van Ka JA (2007) Phytotoxic Nep1-like proteins from the necrotrophic fungus Botrytis cinerea associate with membranes and the nucleus of plant cell. New Phytol 177:493-505

Schwacke R, Hager A (1992) Fungal elicitors induce a transient release of active oxygen species from cultured spruce cells that is dependent on $\mathrm{Ca}^{2+}$ and protein-kinase activity. Planta 187:136-141

Sedlářová M, Lebeda A, Luhová L (2004) The role of active oxygen species in resistance of Lactuca spp. to Bremia lactucae. Acta Fytotech Zootech 7:272-274

Shi J, Fu XZ, Peng T, Huang XS, Fan QJ, Liu JH (2010) Spermine pretreatment confers dehydration tolerance of citrus in vitro plants via modulation of antioxidative capacity and stomatal response. Tree Physiol 30:914-922

Shlezinger N, Minz A, Gur Y, Hatam I, Dagdas YF, Talbot NJ, Sharo A (2011) Anti-apoptotic machinery protects the necrotrophic fungus Botrytis cinerea from host-induced apoptotic like cell death during plant infection. PLoS Pathog 7(8):e100218

Takahama U (1995) Oxidation of hydroxycinnamic acid and hydroxycinnamyl alcohol derivatives by laccase and peroxidase. Interactions among $p$-hydroxyphenyl, guaiacyl and syringyl groups during the oxidation reactions. Physiol Plant 93:61-68

Takahashi S, Seki M, Ishida J, Satou M, Sakurai T, Narusaka M, Kamiya A, Nakajima M, Enju A, Akimaya K, YamaguchiShinozaki K, Shinozaki K (2004) Monitoring the expression profiles of genes induced by hyperosmotic, high salinity, and oxidative stress and abscisic acid treatment in Arabidopsis cell culture using a full length cDNA microarray. Plant Mol Biol 56:29-55

Thaler JS, Owen B, Hoggins VJ (2004) The role of the jasmonate response in plant susceptibility to diverse pathogens with a range of lifestyles. Plant Physiol 135:1-9

Thomma BPHJ, Eggermont K, Penninckx IAMA, Mauch-Mani B, Vogelsang R, Cammue BPA, Broekaert WF (1998) Separate jasmonate-dependent and salicylate-dependent defense-response pathways in Arabidopsis are essential for resistance to distinct microbial pathogens. Proc Natl Acad Sci USA 95:15107-15111

Thordal-Christensen H, Zhang Z, Wei Y, Collinge DB (1997) Subcellular localization of $\mathrm{H}_{2} \mathrm{O}_{2}$ in plants. $\mathrm{H}_{2} \mathrm{O}_{2}$ accumulation in papillae and hypersensitive response during the barleypowdery mildew interaction. Plant J 11:1187-1194

Van Baarlen P, Woltering EJ, Staats M, van Kan JAL (2007) Histochemical and genetic analysis of host and non-host interactions of Arabidopsis with three Botrytis species: an important role for cell death control. Mol Plant Pathol 8(1):41-54

Welinder KG, Justesen AF, Kjaersgard IV, Jensen RB, Rasmussen SK, Jespersen HM, Duroux L (2002) Structural diversity and transcription of class III peroxidases from Arabidopsis thaliana. Eur J Biochem 269:6063-6081

Williamson B, Tudzynski B, Tudzynski P, van Kan JAL (2007) Botrytis cinerea: the cause of grey mould disease. Mol Plant Pathol 8:561-580

Wojtaszek P (1997) Oxidative burst: an early plant response to pathogen infection. Biochem J 322:681-692 